\title{
Development of Basic Motion Learning Models Based on Traditional Games in Early Childhood
}

\author{
Reza Resah Pratama, Sukirno and Syafaruddin \\ Physical Education \\ Universitas Sriwijaya \\ Palembang, Indonesia \\ rezaresah@fkip.unsri.ac.id
}

\begin{abstract}
This study aims to analyze the effectiveness of traditional game-based basic learning models for early childhood. This study uses a pre-experimental research design in the form of one group pre test-post test design. The research sample is 80 children aged 4-6 years Palembang. The instrument used was an observation of the results of the sample performance. The results of the study used the significance difference test obtained Mean $=3,850$ showing the difference between the pre-test and post-test, the t-test results $=6.872$, $\mathrm{df}=79$ and $p$-value $=0.00 \& \mathrm{lt} ; 0.05$ which means that there are significant differences between before and after the treatment of traditional game-based basic motion learning models. The findings in this study are the results of the posttest have positive results with a very strong difference compared to the results of the pre-test so that traditional games can be used for physical education learning materials in kindergarten children aged 4 to 6 years.
\end{abstract}

Keywords: basic motion learning, childhood, traditional games

\section{INTRODUCTION}

Traditional games are forms of local community games created and played as free time for the local community in accordance with local culture and customs as one of the local abilities. For this reason, it is necessary to preserve its existence. These activities are carried out from generation to generation both children and adults to fill their free time [1]. The game is done with fun and excitement, which has a moral message aimed at forming the personality or character of the child. To preserve traditional forms of play, so as not to become extinct, as adults must always convey traditional forms of play to children as early as possible.

Traditional games formerly were very popular and played in the evening by a range of ages [2]. The younger generation is more interested in indulging in a variety of high-tech toys like video games and computers as well as their habit of watching television is more than the wish to play in sports [3, 4]. A study conducted by [2] reported that out of the $77 \%$ who used to play the traditional Yoruba game of Arin, only $18 \%$ of the subjects are still practicing it. This is due to the lack of exposure to traditional games of the current generation on their importance to improving both their health and sporting abilities, especially in early childhood, both through non-formal channels and formal channels as well as through physical education learning as the most effective means of instilling a healthy culture through positive activities.

Children must have been cultivated to do traditional games as early as possible through various activities, especially through physical education teaching and learning activities in early childhood. At the age of 4-6, they require to do physical activity to develop strength, coordination and confidence which will prompt them to lay down the preparation for a healthy lifestyle through obtaining further control over how active they are [5]. Thus, it is suitable to add that this can be accomplished efficiently when the children are involved in physical exercises that are both invigorating and enjoyable.

Development of Physical Education in early childhood through physical activities by prioritizing forms of play is important. The traditional game as local wisdom is given as a stimulus to help accelerate the growth of physical and spiritual development in early childhood. The physical activity can be carried out in the school hall or in the field area of the school. In detail, it is explained that the development of physical activity which relates to sports for early childhood has the characteristics of 1) providing a variety of experiences of movement (multilateral training) in the form of games and competitions, 2) stimulating the development of all five senses, 3) developing imagination/ fantasy, and 4) move to the beat/ song or story. It was further explained that physical activity, as well as sports for young children, are packaged in the form of games or competitions so that children feel interested and get pleasure. One of the school services for early childhood education is provided through kindergarten. The characteristics of children at kindergarten age, in general, have a chronological age of about 4-6 years. Based on [6], gross motor skills and fine motor skills are included in the scope of the level of achievement child development age group 4-6 years. Basic movement material is listed in the early childhood education curriculum which is integrated into children's motor skills. Basic motion consists of locomotor, non-locomotor and manipulative movements. One obstacle is the lack of smooth learning basic movements in PAUD are: (1) inadequate facilities and infrastructure owned, (2) the dependence of early childhood education teachers on standard facilities, and (3) the learning approach to the presentation of basic techniques is also standard in accordance with the established curriculum. These three things cause learning patterns that are less varied and tend to be boring for children. 
traditional game-based learning model for children aged 4-6 years. Given four meetings. The research results relating to the test the effectiveness of the model with the following results.

facilities that will be used in teaching and learning activit In the situation and conditions of Early Childhood Education, space for the children to move in physical development decreases, especially to do sports activities like basic movements so that many teachers must do the provision of general basic motion. There is a need to develop basic motion learning models, and it is very necessary for early childhood who are more varied, creative, as well as equipped with clear visualization of motion so that they can be understood and applied correctly.

The preliminary study showed that there is a need for the development of variations in the basic learning model for early childhood that is more innovative, one of which is by using assistance through traditional games. The teacher will apply the basic motion learning model based on traditional games in carrying out teaching and learning activities in early childhood. Teachers are expected to organize models in teaching and learning activities so that all children want to move or actively move.

Based on the above background, the focus of this research is to analyze the effectiveness of traditional gamebased basic learning models for early childhood in the city of Palembang. This research is expected to be able to enrich scientific revelation and discourse in the development of early childhood physical activities, through various types of traditional games as local wisdom. It is also an alternative game model for motor learning of children aged 4-6 years by providing new experiences in learning kindergarten movements as much as possible (vocabulary movement) and the provision of motion (grammar movement) so that children are met their physical movement needs, and in the end, it will improve the health and physical fitness of children.

\section{METHOD}

This study aims to find the effectiveness of traditional game-based basic learning models for early childhood. This study employed a pre-experimental research design in the form of "one group pretest-posttest design." The research sample is children aged 4-6 years totaling 80 in Palembang. The instrument used was the observation of the results of the sample performance. The steps undertaken in this study are as follows: (1) assigning children as research subjects from 4 different schools totaling 80 children; (2) carrying out basic motion pre-tests conducted in water (3) providing treatment to research subjects by applying traditional game-based basic learning models; (4) carry out basic post-test moves conducted through games; and (5) analyzing the results of the pre-test and post-test using statistical methods (t-test) to find out whether there is a significant influence of the use of the model, then the research flow is carried out from the sample taken by pre-test and treated and then post-test.

\section{RESULTS AND DISCUSSION}

This research was conducted to see how effective the results of applying the model to the research objectives. The effectiveness of the model uses a pre-experimental research design in the form of "one group pretest-posttest design." The results of the model effectiveness test conducted in this study were by performing performance tests on Arimbi Kindergarten, totaling 80 children were treated using a
TABLE I. PAIRED SAMPLES StATISTICS PRETEST DAN POSTTEST

\begin{tabular}{|l|l|c|c|c|c|c|}
\hline & & Mean & N & $\begin{array}{c}\text { Std. Devia- } \\
\text { tion }\end{array}$ & $\begin{array}{c}\text { Std. Error } \\
\text { Mean }\end{array}$ & $\begin{array}{c}\text { Percen- } \\
\text { tage \% }\end{array}$ \\
\hline Pair 1 & Pre-test & 6.2850 & 80 & 6.76676 & .66992 & $47 \%$ \\
\cline { 2 - 7 } & $\begin{array}{l}\text { Post- } \\
\text { test }\end{array}$ & 9.5750 & 80 & 8.25204 & .83042 & $95 \%$ \\
\hline
\end{tabular}

Based on the summary in Table 1 , the average score of the test based on observations before given a basic learning model based on traditional games for children aged 4-6 years was 6.2850 before the post-test and after being given an increased treatment to 9.5750 . Percentage before treatment $46 \%$ (37 subjects) who can take the test, while after treatment $85 \%$ (68 subjects) successfully took the test. This proves that the basic motion learning model based on traditional games can approach the predetermined goals and the objectives of this traditional game are achieved, namely developing the locomotor motion of children that leads to goals in building self-confidence, courage, and physicalmotor development, and balance the body, this is in accordance with the results of the study of $[7,8,9]$ which traditional games contribute differently to physical fitness.

In the significance test of the difference using SPSS, the Mean $=3,850$ shows the difference between the pretest and posttest, the t-test results $=6.872, \mathrm{df}=79$ and $\mathrm{p}$-value $=0.00$ $<0.05$, which means that there are significant differences between before and after the treatment of learning models basic motion-based traditional game. Where the results of the post-test have positive results with a very strong difference compared to the results of the pretest. Therefore, traditional games can be used for physical education learning materials in kindergarten children aged 4 to 6 years. Then, it can be concluded that the traditional game model can improve the physical abilities, motor skills, and emotional intelligence of children aged 4-6 years. This is in line with the results of research [10] the present study discovered that the traditional games intervention program could be efficient in the improvement of motor fitness performance, ie, agility, reaction time, speed and balance, in fact, each traditional game intervention also showed differences in the effect of each component of motor fitness besides [11].

TABLE II. RESUlts of PAIRED SAMPles TeSt PRE-TeSt DAN POSTTEST

\begin{tabular}{|l|l|l|c|l|l|c|}
\hline & Mean & $\begin{array}{c}\text { Std. } \\
\text { Deviation }\end{array}$ & $\begin{array}{c}\text { Std. } \\
\text { Error } \\
\text { Mean }\end{array}$ & t & df & $\begin{array}{c}\text { Sig- } \\
\mathbf{2} \\
\text { tailed }\end{array}$ \\
\hline $\begin{array}{l}\text { Pretest } \\
- \\
\text { Postest }\end{array}$ & 3.85000 & 5.67502 & .76602 & 6.872 & 79 & .000 \\
\hline
\end{tabular}

The research results have shown the improvement of students' relations after traditional games implementation, in addition to the research results of [12] traditional games could improve on the gross motor skill development of an early childhood, and the results of research by [13] confirm 
[4] H. Akbari, B. Abdoli, M. Shafizadehkenari, H. Khalaji, S. Hajihosseini, and V. Ziaee, "The effect of traditional games in fundamental motor skill development in 7-9-year-old boys," Iranian Journal of Pediatrics, vol. 19, no. 2, pp.123-129, 2009.

\section{CONCLUSION}

Based on the results of the study, it is found that the traditional game-based basic learning model can approach the predetermined targets and the objectives of this traditional game are achieved, namely developing children's locomotor motion that leads to goals in building selfconfidence, courage, and physical-motor development, and balance body. The traditional game-based model can be used as a teacher's reference in enhancing motor physical development of children aged 4-6 years.

\section{ACKNOWLEDGMENT}

The researchers thank Sriwijaya University for providing funding to conduct this research through a competitive scheme so that this research can run smoothly, as well as to the research members both colleagues and students who have helped in the research process.

\section{REFERENCES}

[1] S. Sukirno, Permainan kecil dan Olahraga Tradisional dalam Pembelajaran. Penjaskes. Palembang: Unsri Press. 2016.

[2] T. Ekunsanmi, "A note on the current status of Arin, a Yoruba traditional game played with the seeds of dioclea reflexa," Journal of Life Sciences, vol. 6, no.3, pp.349-353. 2012.

[3] M. Zulkifli, A. Putra, M. Yusof, S. Anuwar, N. Z. A. Norzaman, and A. F. Razali, "Re-creation of Malaysian traditional game namely 'Baling Selipar': a critical review," International Journal of Science, Environment and Technology, vol.3, no.6, pp.2084-2089, 2014.

[5] A. J. Olufemi and R. M. Musa, "Assessment of wellness status among a multi-ethnic based adult sample," Int J Phy Edu Sports Health,vol. 3, no. 4, pp. 299-301, 2016.

[6] K. Kemendiknas, Pedoman Pengembangan program pembelajaran di Taman Kanak-kanak. Jakarta: Kemndiknas. 2010.

[7] F. Pasand, M. Ahmadian, M. J. Alsaadi, and M. Bahramian, "Impact of traditional exercises on perceptual-motor development in elementary school girl students," Indian Journal of Fundamental and Applied Life Sciences, vol.4, no.3, pp.1297-1302, 2014

[8] M. Rouhi, "Iranian traditional games pedagogy and their importance in improving physical and psychological aspects of elementary school students," Journal of American Science, vol. 8, no. 9, 2012

[9] L. Tatira, "Traditional games of Shona children," The Journal of Pan African Studies, vol.7, no.4, pp. 156-175, 2014

[10] M. A. Gipit, M. R. Abdullah, R. M. Musa, N. A. Kosni, and A. B. H. M. Maliki, "The effect of traditional games intervention programme in the enhancement school-age children's motor skills: A preliminary study," Malaysian Journal of Movement, Health \& Exercise, vol. 6, no.2, 2017.

[11] T. Kovačević, and S. Opić, "Contribution of traditional games to the quality of students' relations and frequency of students' socialization in primary education," Croation Journal of Education, vol. 16, no.1, pp.95-112, 2014.

[12] B. Abdullah, S. Amri, K. L. Yee, and B. A. Samah, "The impact of traditional games on the gross motor skill development of an early childhood," The social sciences, vol. 8, no. 6, pp.590-595, 2013.

[13] P. Lavega, J. I Alonso, J. Etxebeste, F. Lagardera, and J. March, "Relationship between traditional games and the intensity of emotions experienced by participants," Research quarterly for exercise and sport, vol. 85, no. 4, pp.457-467, 2014. 